\title{
The Security and Stability Analysis Of 500kV West Channel To Shanxi Datong Power Grid
}

\author{
Xinyuan $\mathrm{Liu}^{1}$, Xiaojia Zhai ${ }^{2}$, Huiping Zheng ${ }^{1}$ and Weiwen Duan ${ }^{1}$ \\ ${ }^{1}$ State Grid Shanxi Electric Power Research Institute, Qingnian Road NO.6, Taiyuan, Shanxi Province, China \\ ${ }^{2}$ State Grid Shanxi Electric Power Company Taiyuan Power supply branch, Bingzhou Road NO.89, Shanxi Province, China
}

\begin{abstract}
This paper researches the limit of Shanxi Datong power grid static stability, transmission capacity, security and stability of power grid characteristics under the serious fault by simulation after the commissioning of $500 \mathrm{kV}$ west channel. Then compared with the pre production, the importance and necessity of west channel production are demonstrated.
\end{abstract}

Keywords-west channel; Datong power grid; security and stability; transmission capacity

\section{INTRODUCTION}

Shanxi, as a major energy province, is to transport large quantities of electricity to the surrounding areas. Datong Power Grid in northern Shanxi is connected with the Shanxi power grid by Double circuit line of Shenyan and also is connected with the Beijing power grid through the Datong to three circuit line of Fangshan. the amount of security measures is too large after Shenyan double N-2 serious faults, which may cause the Datong Power Grid and grid splitting, affect the safe and stable operation of the whole North China Power Grid.

It is planning and production Yantong - Pinglu - Wuzhai $500 \mathrm{kV}$ West Channel, which ensures Datong Power Grid in complex situations can be maintained stable in 2017, and enhance the links between Datong grid and the main grid. After the Western channel operation, it is increased to six $500 \mathrm{kV}$ lines, respectively, three circuit line of Datong Fangshan (hereinafter referred to as Da-Fang three ), doublecircuit line of Shener -Yantong (line of Shen-Yan double) and the circuit line of Pinglu - Yantong (line of Ping-Yan ).The topology of Datong $500 \mathrm{kV}$ Power Grid is shown in figure I. There are greatly changed in the static, transient stability characteristics and transmission capacity of Datong grid after the Western channel operation. Therefore, there is very important practical significance to study deeply the Western channel on the security and stability of Shanxi Datong power grid.

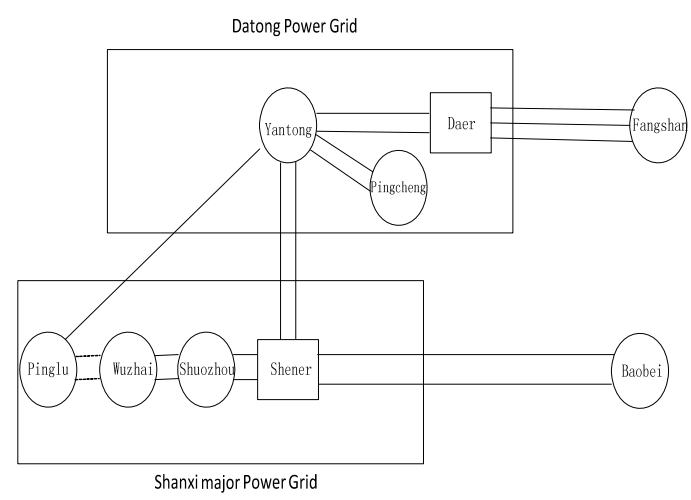

FIGURE I. THE TOPOLOGY OF DATONG 500KV POWER GRID

\section{CALCULATION PROgRAm AND CALCUlation CONDITION}

A. Calculation Program

It is used the PSD System Software Tools of China Electric Power Research Institute, the power flow of PSDBPA and the transient stability program of PSD-BPA.

\section{B. Calculation Conditions}

- The calculation network includes all $220 \mathrm{kV}$ and the network in Shanxi, taking into account the 2017 Shanxi power grid, transmission and substation planning and load conditions.

- The generator model put to use the model of Ed and $\mathrm{Eq}$, and the excitation, PSS and the speed regulation system are considered.

- Load model, using $40 \%$ constant impedance and $60 \%$ motor model.

\section{ThE STATIC STABILITY LIMIT OF DATONG POWER} NETWORK AFTER THE OPERATION OF THE WEST CHANNEL

It is increased $500 \mathrm{kV}$ line of Ping Yan between the Datong power grid and the main grid connection line of Shanxi after the operation of West channel. With the practical engineering algorithm, respectively of Datong power network in normal way, line of Shen-Yan double out of service, line of Da-Fang three out of service, it is figured out the limit of static stability with simulation delivery section. The simulation curves are 
shown in Figure II-IV and the calculated results are shown in Table I .

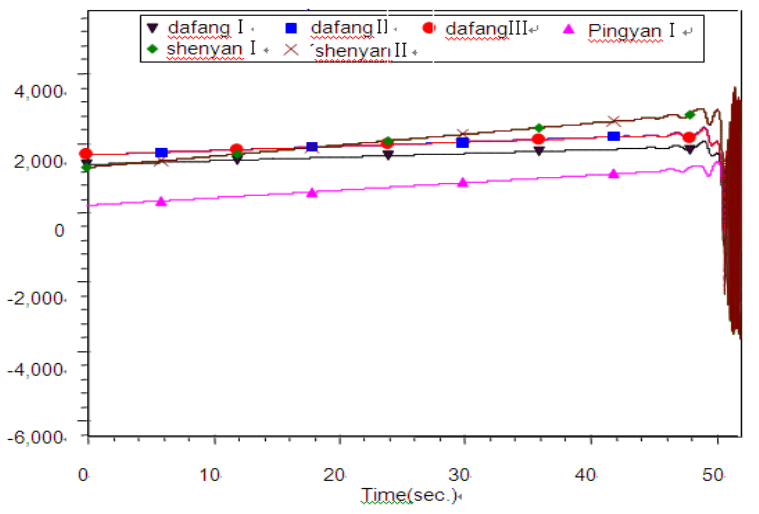

FIGURE II. THE STATIC STABILITY LIMIT OF EXTERNAL POWER SUPPLY SECTION OF DATONG POWER GRID IN NORMAL MODE

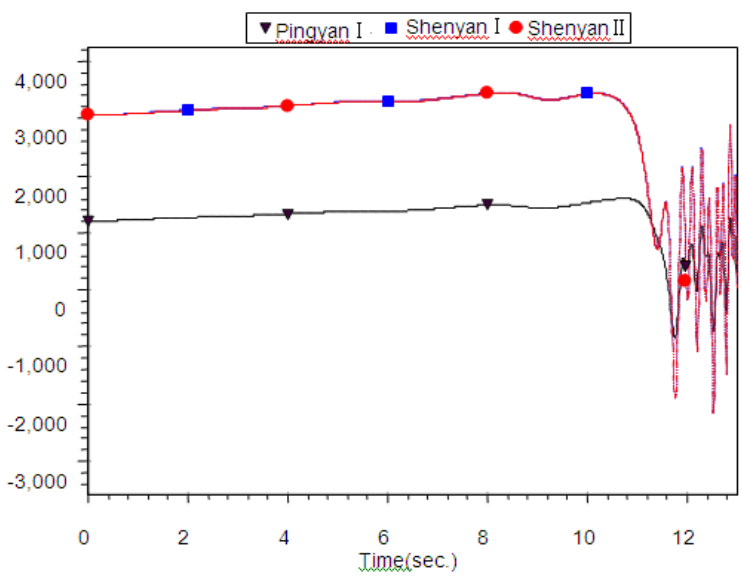

FIGURE III. THE STATIC STABILITY LIMIT OF DATONG POWER GRID TRANSMISSION SECTION AFTER THE THREE CIRCUIT LINE OF DA-FANG OUT OF SERVICE

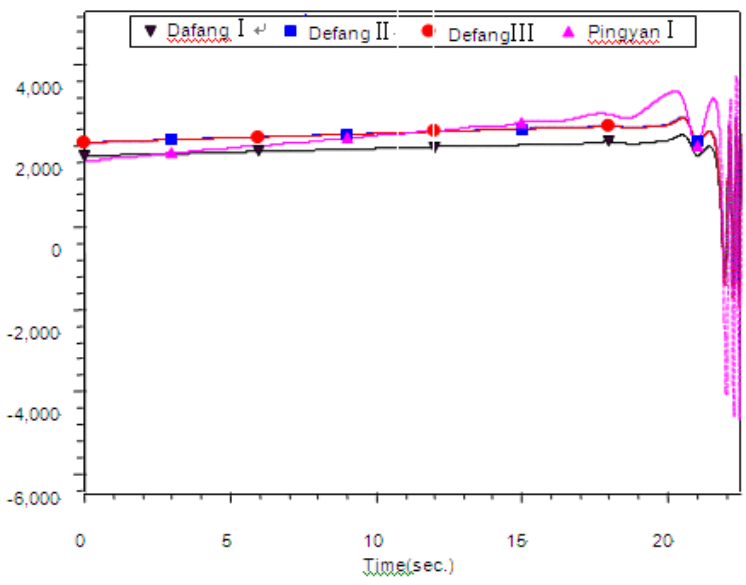

FIGURE IV. THE STATIC STABILITY LIMIT OF DATONG POWER GRID TRANSMISSION SECTION AFTER THE DOUBLE CIRCUIT LINE OF SHEN-YAN OUT OF SERVICE
TABLE I. THE COMPARISON TABLE OF THE STATIC STABILITY LIMIT OF DATONG POWER GRID TRANSMISSION SECTION UNDER WEST CHANNEL OPERATION BEFORE AND AFTER

\begin{tabular}{|c|c|c|c|c|c|c|}
\hline $\begin{array}{c}\text { Operation } \\
\text { mode }\end{array}$ & $\begin{array}{c}\text { Grid } \\
\text { structure }\end{array}$ & Section composition & \begin{tabular}{|c|} 
Static \\
stability \\
limit of \\
external \\
delivery \\
section
\end{tabular} & $\begin{array}{c}\text { double- } \\
\text { circuit } \\
\text { line of } \\
\text { Shen } \\
\text { yan }\end{array}$ & $\begin{array}{c}\text { three } \\
\text { circuit } \\
\text { line of } \\
\text { Dafang }\end{array}$ & $\begin{array}{l}\text { line } \\
\text { of } \\
\text { Ping- } \\
\text { Yan }\end{array}$ \\
\hline \multirow[b]{2}{*}{$\begin{array}{c}\text { Nomal } \\
\text { mode }\end{array}$} & $\begin{array}{c}\text { before } \\
\text { operation }\end{array}$ & $\begin{array}{l}\text { Line of Dafang three } \\
\text { and Shenyan double }\end{array}$ & 12760 & 5527 & 7233 & - \\
\hline & $\begin{array}{c}\text { after } \\
\text { operation }\end{array}$ & $\begin{array}{l}\text { line of Dafang } \\
\text { three ,Shenyan double } \\
\text { and Ping-Yan }\end{array}$ & 14468 & 6014 & 6993 & 1461 \\
\hline \multirow{2}{*}{$\begin{array}{l}\text { the three } \\
\text { circuit line } \\
\text { of Dafang } \\
\text { out of } \\
\text { service }\end{array}$} & $\begin{array}{c}\text { operation } \\
\text { before }\end{array}$ & $\begin{array}{l}\text { Line of Dafang and } \\
\text { Shenyan double }\end{array}$ & 10180 & 7467 & 2713 & - \\
\hline & $\begin{array}{c}\text { operation } \\
\text { after }\end{array}$ & $\begin{array}{c}\text { Line of } \\
\begin{array}{c}\text { Dafang ,Shenyandouble } \\
\text { andPing-Yan }\end{array}\end{array}$ & 11117 & 6594 & 2856 & 1667 \\
\hline \multirow{2}{*}{$\begin{array}{c}\text { the double } \\
\text { circuit line } \\
\text { of } \\
\text { Shenyan } \\
\text { out of } \\
\text { service }\end{array}$} & $\begin{array}{l}\text { operation } \\
\text { before }\end{array}$ & line of Dafang three & 6739 & - & 6739 & - \\
\hline & $\begin{array}{c}\text { operation } \\
\text { after }\end{array}$ & $\begin{array}{l}\text { line of Dafang three } \\
\text { and Ping-Yan }\end{array}$ & 10983 & - & 7650 & 3333 \\
\hline
\end{tabular}

From the Table I we can see that the static stability limit of Datong Power Grid transmission section is increased under the three situations after the western channel is put into operation. In normal mode, the static stability limit is $14468 \mathrm{MW}$, which improved the $1708 \mathrm{MW}$, the static stability limit obviously increases to $10983 \mathrm{MW}$ after Shen-yan double out of service and improve the 4244MW.

IV. The Transmission CAPACITY ANALysis OF DATONG POWER GRID AFTER THE OPERATION OF THE WEST CHANNEL

Before West Channel production, Datong power grid transmission capacity limit for 6700MW, which is included 4200 MW of three circuit line of Datong - Fangshan and 2500MW of double-circuit line of Shener -Yantong.

After the operation of the west channel, the transmission capacity of Datong Power Grid has been improved. In 2017, the Datong power grid installed to $10500 \mathrm{MW}$. Under the Datong power unit fully open, the transmission capacity of Datong power grid by six circuit is $8008 \mathrm{MW}$, which is included 4902MW of three circuit line of Dafang, 311mw of the circuit line of Pingyan, and 2795MW of double-circuit line of Shenyan. The Shenyan double $\mathrm{N}-1$, and the line of II 2098MW, which are fully open .Therefore, under the thermal stability limit of Shenyan double $\mathrm{N}-1$ ( $4 * 300$ wire and flow limit $2100 \mathrm{MW}$ ), the transmission capacity of Datong power grid is $8000 \mathrm{MW}$, improved $1300 \mathrm{MW}$. The power flow diagram of Datong Power Grid after the western channel is put into operation as shown in figure $\mathrm{V}$. 


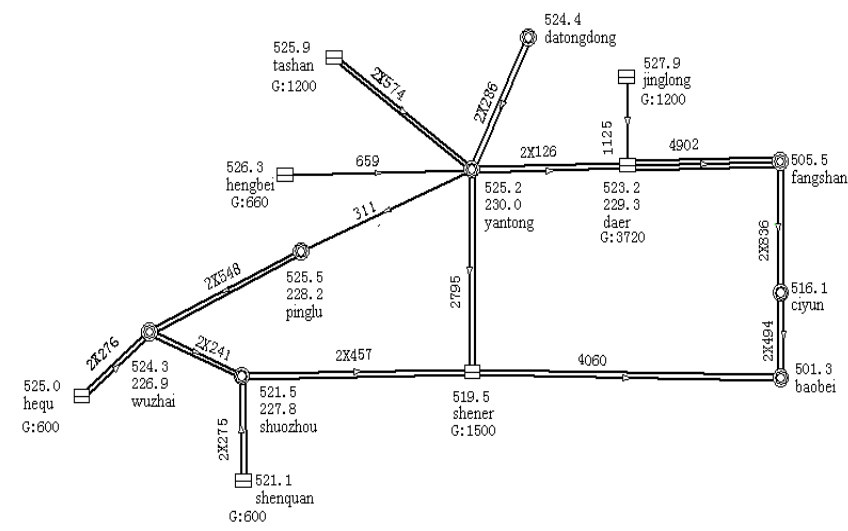

FIGURE V. THE POWER FLOW DIAGRAM OF DATONG POWER GRID AFTER THE OPERATION OF THE WESTERN CHANNEL

\section{SAFETy AND Stability ANalysis Of Datong POWER GRID UNDER THE SERIOUS FAULTS AFTER THE OPERATION OF THE WEST CHANNEL}

The West channel put into production and operation before and after, the stability calculation and analysis is used respectively on the fault of Dafang double line and Shenyan double line. The stable calculation results are shown in TABLE II and TABLE III.

TABLE II. SAFETY AND STABILITY ANALYSIS OF DATONG POWER GRID UNDER THE SERIOUS FAULTS BEFORE THE OPERATION OF THE WEST CHANNEL

\begin{tabular}{|c|c|c|c|c|}
\hline NO. & $\begin{array}{l}\text { the fault } \\
\text { location }\end{array}$ & Fault side & $\begin{array}{c}\text { stable } \\
\text { state }\end{array}$ & security controls \\
\hline 1 & $\begin{array}{c}\text { Dafang } \\
\text { double N-2 }\end{array}$ & Datong side & stable & no \\
\hline 2 & $\begin{array}{c}\text { Dafang } \\
\text { double N-2 }\end{array}$ & $\begin{array}{l}\text { Fangshan } \\
\text { side }\end{array}$ & stable & no \\
\hline 3 & $\begin{array}{c}\text { Shenyan } \\
\text { double N-2 }\end{array}$ & $\begin{array}{l}\text { Yantong } \\
\text { side }\end{array}$ & astable & $\begin{array}{c}\text { Removal of } \\
\text { 1600MW unit, } \\
\text { power grid system } \\
\text { is stable }\end{array}$ \\
\hline 4 & $\begin{array}{c}\text { Shenyan } \\
\text { double N-2 }\end{array}$ & $\begin{array}{l}\text { Shener } \\
\text { side }\end{array}$ & astable & $\begin{array}{c}\text { Removal of } \\
\text { 5200MW unit, } \\
\text { power grid system } \\
\text { is stable }\end{array}$ \\
\hline
\end{tabular}

TABLE III. SAFETY AND STABILITY ANALYSIS OF DATONG POWER GRID UNDER THE SERIOUS FAULTS AFTER THE OPERATION OF THE WEST CHANNEL

\begin{tabular}{|c|c|c|c|c|}
\hline $\begin{array}{c}\text { NO } \\
\boldsymbol{1}\end{array}$ & $\begin{array}{c}\text { the fault } \\
\text { location }\end{array}$ & Fault side & $\begin{array}{c}\text { stable } \\
\text { state }\end{array}$ & security controls \\
\hline 1 & $\begin{array}{c}\text { Dafang } \\
\text { double N-2 }\end{array}$ & Datong side & stable & no \\
\hline 2 & $\begin{array}{c}\text { Dafang } \\
\text { double N-2 }\end{array}$ & $\begin{array}{c}\text { Fangshan } \\
\text { side }\end{array}$ & stable & no \\
\hline 3 & $\begin{array}{c}\text { Shenyan } \\
\text { double N-2 }\end{array}$ & $\begin{array}{c}\text { Yantong } \\
\text { side }\end{array}$ & astable & $\begin{array}{c}\text { Removal of } \\
\text { 200MW unit, } \\
\text { power grid system } \\
\text { is stable }\end{array}$ \\
\hline 4 & $\begin{array}{c}\text { Shenyan } \\
\text { double N-2 }\end{array}$ & $\begin{array}{c}\text { Shener } \\
\text { side }\end{array}$ & astable & $\begin{array}{c}\text { Removal of } \\
\text { powner grid system } \\
\text { is stable }\end{array}$ \\
\hline
\end{tabular}

Comparisons of Table II and Table III:
- After the first and end of the Dafang N-2 fault, the system can keep stable operation.

- After the first and end of the Shenyan N-2 fault, the system cannot keep stable operation. the system can maintain stable operation after taking control measures. The 3240MW unit can maintain the stable operation of the N-2 unit after the fault of the Shenyan N-2, when Removal of 5500MW unit, the power grid system is stable, and the stability of the system is greatly improved.

For the output system, the grid construction has a positive impact on the safe and stable operation of the power grid, but also improves the ability of the system. According to the classical areas of the law, the grid is enhanced, the static stability of the outer section is improved, and the increase of the reduction area of the rear system is increased. In normal operation mode, the power grid connection is more closely. After the occurrence of Shenyan N-2 fault, the stability of Datong power grid is effectively improved.

\section{CONCLUSIONS}

For the north of Shanxi power grid planning and construction of the Yantong - Pinglu - Wuzhai 500kV west channel in 2017, this research prospect the Datong power grid stability characteristics and the amount of removal under the serious fault after the operation of the west channel. The main conclusions are:

- After the operation of West channel, Datong power grid transmission capacity is $8000 \mathrm{MW}$, which increased by $1300 \mathrm{MW}$ restricted by the thermal stability limit of Shenyan N-1 fault.

- After commissioning of the west channel, it is enhanced the connection of Datong Power Grid and Shanxi main grid effectively. The static stability limit of the northern Shanxi section is 10983MW, which improves 4244MW obviously.

- After commissioning of West channel, the deceleration area of Datong power grid unit increased after Shenyan double circuit N-2 fault, which is conducive to the recovery of the system to a stable state. Furthermore, the amounts of removal of safety control decreased from 3240MW to 5200MW.

Thus, $500 \mathrm{kV}$ west channel of Yantong - Pinglu - Wuzhai could effectively improve the security and stability of Datong power grid, which has important practical significance to ensure the safe and stable operation of the North China Power Grid.

\section{REFERENCES}

[1] Li Guangqi. The Transient analysis of Power System. Beijing: China Electric Power Press, 2006,pp.204-210.

[2] Zheng-qiu Wu,Kuang Wen-kai, and Yang Hong-bo. "The Analysis on Single Generator Equal Area Criterion based on Power System Transient Stabilit,"in Proceedings of the CSU-EPSA,vol.22,4th ed,2010,pp.64-70.

[3] Zhu Fang,Tang Yong,and Zhang Dongxia. "Study on dynamic stability problems of AC interconnected area power grids in China and their 
solutions,”in Power Systems Technology , vol.28,15th ed.Beijing: Power Systems Technology .2004,pp.1-5.

[4] Han Zhenxiang,Xue Yusheng, and Qiu Jiaju. “A review of CIGRE’2000 on power system interconnection,"in Automation of

[5] Electric Power Systems,vol.24.Beijing:Electric Power Systems 2000,pp.1-4.

[6] M. ponnavaikko, K. S. Prakasa Rao, Optimal Distribution System Planning,"IEEE Transactions on Power Apparatus and System, vol.PAS100,6th ed,June, 1981,pp.2969 -2977.

[7] Yongning Chi, Yanhua Liu, and Weisheng Wang, "Study on impact of wind power integration on power system," in Power System Technology, Vol.32,Beijing:Academic,2007.pp. 47-52.

[8] Yazhou Lei., "Studies on the wind farm integration into power system," in Automation of Electric Power Systems", Vol.27, Beijing:Academic,2003.pp.84-89.

[9] Zhu Fang,Zhao Hongguang, and Liu Zenghuang. "The influence of large power grid interconnected on power system dynamic stability."in Proceedings of the CSEE,vol.27,1st ed, Beijing:Academic,2007,pp.1-7.

[10] Ren Wei,Fang Dazhong,and Chen Jiarong. "A fast algorithm to generation capacity tripped by emergency control for transient stability of large power system.”in Power System Technology,vol.32,19th ed, Beijing:Academic,2008,pp. 10-15.

[11] Li Qiang,Lin Tao, and Gao Yuxi. "Simulation of transient in interconnection test of regional power grids,"in Power System Technology, vol.34,3rd ed,Beijing:Academic,2010,pp85-89. 